\begin{tabular}{|c|c|c|}
\hline $\begin{array}{l}\text { OPEN ACCESS } \\
\text { Vol. } 1 \text { No. 2: 1-7 } \\
\text { Tahun } 2018 \\
\text { Artikel penelitian 直 }\end{array}$ & $\begin{array}{l}\text { Jutrieal Alkuditilestatri } \\
\text { E-ISSN: 2598-8204 } \\
\frac{\text { https://ojs.umrah.ac.id/index.php/akuatiklestari }}{\text { DOI : https://doi.org/10.31629/.v1i2.2287 }}\end{array}$ & $\frac{\vdots}{a=}$ \\
\hline
\end{tabular}

\title{
Eksistensi Bacillariophyceae dan Chlorophyceae di Perairan Sei Timun Kota Tanjungpinang, Kepulauan Riau
}

\author{
The existence of Bacillariophyceae and Chlorophyceae in Waters Sei Timun Tanjungpinang City, \\ Province of Kepulauan Riau
}

Ilham Haryoko1 ${ }^{\bowtie}$, Winny Retna Melani ${ }^{1}$, Tri Apriadi ${ }^{1}$

${ }^{1}$ Manajemen Sumberdaya Perairan, Fakultas Ilmu Kelautan dan Perikanan, Universitas Maritim Raja Ali Haji, Tanjungpinang, Indonesia 29111

\section{$\square$ Info Artikel:}

Diterima: 1 Maret 2018

Revisi: 13 Maret 2018

Disetujui: 17 Mei 2018

Dipublikasi: 30 Mei 2018

\section{Keyword:}

Bacillariophyceae, Chlorophyceae, Perairan Sei Timun, Tanjungpinang,

\section{$\bowtie$ Penulis Korespondensi:}

Ilham Haryoko

Manajemen Sumberdaya Perairan,

Fakultas Ilmu Kelautan dan Perikanan,

Universitas Maritim Raja Ali Haji,

Tanjungpinang, Indonesia 29111

Email: tanyoko13@gmail.com

\begin{abstract}
ABSTRAK. Penelitian mengenai eksistensi Bacillariophyceae dan Chlorophyceae dilakukan di Perairan Sei Timun, Kelurahan Air Raja, Kecamatan Tanjungpinang Timur, Kota Tanjungpinang, Kepulauan Riau. Tujuan penelitian ini adalah untuk mengetahui Eksistensi Bacillariophyceae dan Chlorophyceae di Perairan Sei Timun. Penelitian ini dilakukan dengan metode Random Sampling sebanyak 30 titik pengamatan di Perairan Sei Timun. Analisis data fitoplankton menggunakan indeks similaritas Bray-Curtis. Analisis kualitas air menggunakan indeks similaritas Canberra. Hasil penelitian menunjukan kelimpahan rata-rata fitoplantkon di Perairan Sei Timun mencapai $21299,4 \mathrm{sel} / \mathrm{L}$. Kelimpahan rata-rata tertinggi pada kelas Bacillariophyceae yaitu genera Pleurosigma sp. sebesar $1701,4 \mathrm{sel} / \mathrm{L}$ dan kelimpahan rata-rata terendah yaitu pada genera Rhizoselenia sp. sebesar 799,1 sel/L, sedangkan kelimpahan rata-rata tertinggi pada kelas Chlorophyceae yaitu pada genera Mougeotia sp. sebesar 4276,6 sel/L dan kelimpahan rata-rata terendah yaitu pada genera Micrasterias sp. sebesar 302,2 sel/L. Berdasarkan hasil penelitian dapat disimpulkan bahwa keberadaan fitoplankton kelas Bacillariophyceae sebanyak 4 genera dan Chlorophyceae sebanyak 8 genera di Perairan Sei Timun.
\end{abstract}

\begin{abstract}
Research on the existence of Bacillariophyceae and Chlorophyceaehave been done in waters Sei Timun, Tanjungpinang City, Province of Kepulauan Riau. The objective of this study was to know the existence of Bacillariophyceae and Chlorophyceae in Sei Timun waters. This research was used Random Sampling method with 30 observation points in Sei Timun. Analysis of Phytoplankton data used the Bray-Curtis similarity index. Analysis of water quality used Canberra's similarity index. The results of this this research showed the average abundance of phytoplankton in Sei Timun waters reached 21299.4 cells/L. The highest average abundance in the Bacillariophyceae class namely Pleurosigma sp. amounting to 1701.4 cells/L and the lowest mean abundance is the Rhizoselenia sp. amounting to 799.1 cells/L. While the highest abundance in the Chlorophyceae class is in the genus Mougeotia sp. amounting to 4276.6 cells/L and the lowest average abundance is the Micrasterias sp. amounting to 302.2 cells/L. Based on the results of the research it can be concluded that the presence the phytoplankton of Bacillariophyceae class were 4 genera and Chlorophyceaewere 8 genera in Sei Timun waters.
\end{abstract}

How to cite this article:

Haryoko, I., Melani, W.R., \& Apriadi, T. (2018). Eksistensi Bacillariophyceae dan Chlorophyceae di Perairan Sei Timun Kota Tanjungpinang, Kepulauan Riau. Jurnal Akuatiklestari. 1(2): 1-7. https://doi.org/10.31629/.v1i2.2287

\section{PENDAHULUAN}

Pulau Bintan merupakan salah satu pulau utama di Provinsi Kepulauan Riau yang memiliki banyak perairan baik perairan menggenang dan mengalir. Salah satunya Perairan Sei Timun yang berada di Kelurahan Air Raja, Kecamatan Tanjungpinang Timur, Kota Tanjungpinang. Perairan Sei Timun memiliki luas sekitar 17,27 Ha. Awalnya Perairan Sei Timun merupakan aliran sungai pasang surut yang pasokan airnya berasal dari air laut. Seiring pesatnya pembangunan yang ada di Kota Tanjungpinang, pada tahun 2005 adanya pembuatan jalan aspal sehingga aliran sungai tadi ditimbun dan dibendung untuk dibuat jalur transportasi darat. Dulunya perairan Sei Timun airnya asin kini menjadi air tawar disebabkan air laut tidak bisa masuk lagi ke dalam waduk tersebut dan juga ada sumber mata air tawar serta limpasanlimpasan masukan air lainnya.

Keberadaan Perairan Sei Timun sangat penting bagi masyarakat. Dalam kurun 12 tahun terakhir, Perairan Sei Timun belum pernah mengalami surut atau kekeringan. Berbagai jenis ikan yang ada di perairan tersebut antara lain ikan bawal, 
gabus pasir, bandeng, nila, lele, patin, serta udang lobster (Azizah, 2017). Ada juga ikan berasal pemberian benih dari Dinas Kelautan dan Perikanan yang diberikan untuk masyarakat setempat, yaitu ikan nila dan ikan lele. Melihat banyaknya ikan-ikan yang berada di Perairan Sei Timun, banyak masyarakat memanfaatkan untuk melakukan kegiatan budidaya, menangkap ikan dengan alat pancing, bubu ikan, dan jala ikan. Selain bidang perikanan, Perairan Sei Timun digunakan juga untuk kegiatan pengairan kebun, dan lain-lainnya.

Banyaknya aktivitas yang dilakukan di Perairan Sei Timun terutama pada bidang perikanan, tentu sangat berkaitan erat dengan kualitas perairan (Lestari, 2018). Namun belum ada informasi tentang kualitas perairan, dalam hal ini fitoplankton di perairan Sei Timun. Menurut Nyabkken (1992), fitoplankton merupakan organisme renik yang melayang-layang dalam air atau mempunyai kemampuan renang yang sangat lemah dan pergerakannya selalu dipengaruhi oleh pergerakan massa air. Keberadaan fitoplankton sangat berpengaruh terhadap kehidupan di perairan karena memegang peranan penting sebagai makanan bagi berbagai organisme laut. Selain sebagai dasar dari rantai pakan (primary producer), fitoplankton juga merupakan salah satu parameter tingkat kesuburan suatu perairan (Syafriani \& Apriadi, 2017). Terdapat hubungan positif antara kelimpahan fitoplankton dengan produktivitas perairan tinggi maka perairan tersebut cenderung memiliki produktivitas yang tinggi pula (Yuliana et al., 2012). Berdasarkan hal tersebut untuk itu perlu adanya penelitian mengenai eksistensi Bacillariophyceae dan Chlorophyceae di perairan Sei Timun, Kota Tanjungpinang, Kepulauan Riau.

\section{BAHAN DAN METODE}

\subsection{Waktu dan Tempat}

Penelitian ini dilakukan pada bulan Mei 2017 di perairan Sei Timun Kota Tanjungpinang, Kepulauan Riau. Peta lokasi penelitian dapat dilihat pada Gambar 1.

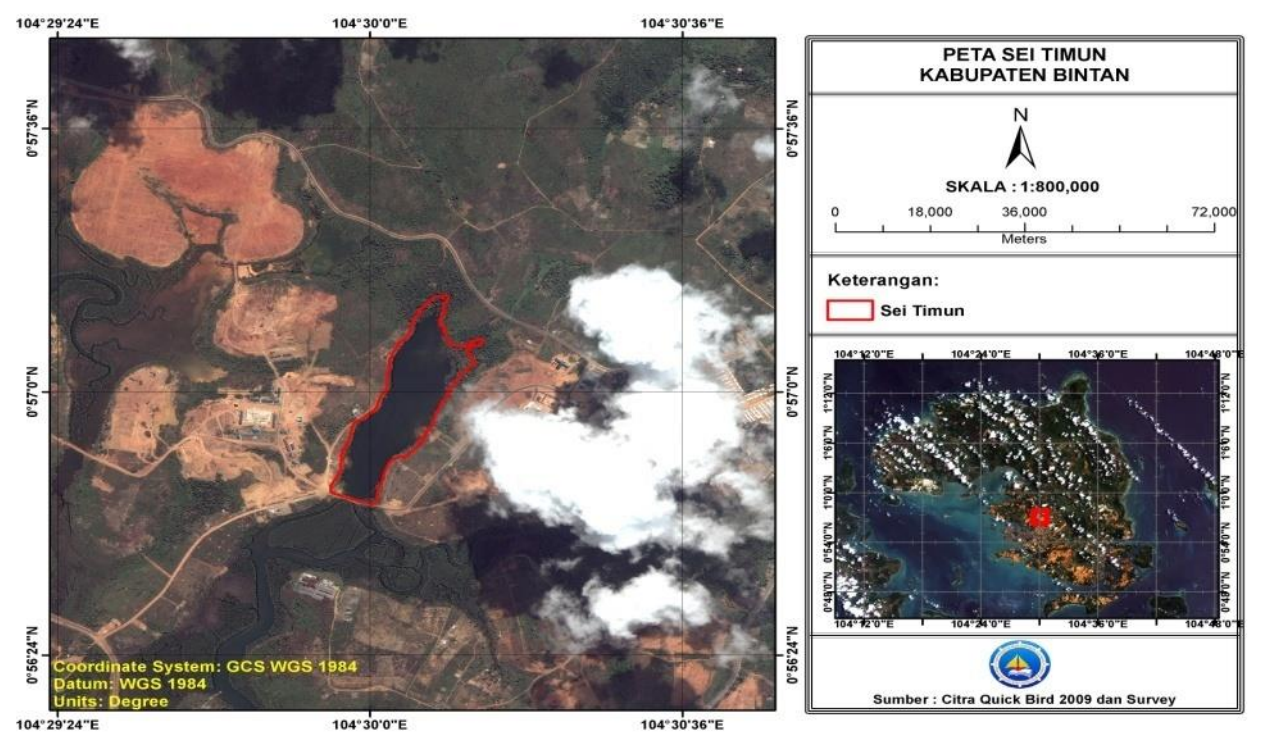

Gambar 1. Peta lokasi penelitian

\subsection{Alat dan Bahan}

Peralatan yang digunakan dalam penelitian ini antara lain : GPS, perahu, plankton net ukuran mata jaring 40 $\mu \mathrm{m}$, ember ukuran 10 liter, botol sampel, cool box, secchi disk, do meter, hand refratometer, current meter, van dorn water sampler, mikroskop, pipet tetes, cover glass, sedgewich rafter counting chaber (SRC), kamera, buku identifikasi fitoplankton. Bahan yang digunakan dalam penelitian ini yaitu air sampel, lugal $4 \%$ dan akuades.

\subsection{Prosedur Penelitian}

Metode penelitian yang digunakan dalam penentuan lokasi sampling untuk pengambilan fitoplankton adalah Random Sampling menggunakan software VSP (Visual Sampel Plan) dengan citra Quick Bird. Titik pengamatan ditetapkan sebanyak 30 titik di Perairan Sei Timun. Titik koordinat penelitian dapat dilihat pada Tabel 1.

\subsection{Teknik Pengumpulan Data}

Pengambilan sampel dilakukan dengan metode statis, caranya sampel air diambil menggunakan ember berkapasitas 10 liter sebanyak 100 liter pada kedalaman tertentu sesuai dengan hasil pengukuran kecerahan perairan lalu, disaring dengan menggunakan plankton net dengan ukuran jaring $40 \mu \mathrm{m}$. Sampel fitoplankton yang terjaring akan terkumpul dalam bucket yang selanjutnya dituangkan ke dalam botol sampel dan diberi pengawet menggunakan lugol 4\% ditetes sampai warna sampel berubah menjadi warna merah bata dan diberi label. 
Identifikasi sampel dilakukan di Laboratorium Fakultas Ilmu Kelautan dan Perikanan Universitas Maritim Raja Ali Haji. Sampel diamati menggunakan mikroskop dengan perbesaran 10x, 40x dan 100x. Sampel diambil menggunakan pipet tetes dan dituangkan kedalam gelas objek SRC sebanyak $1 \mathrm{~mL}$ lalu diamati. Selanjutnya diidentifikasi dengan menggunakan buku identifikasi Fitoplankton (Basmi, 1999) dan bantuan buku lainnya.

Tabel 1. Titik koordinat lokasi penelitian di Perairan Sei Timun

\begin{tabular}{cccccc} 
Titik Lokasi & \multicolumn{3}{c}{ Titik Koordinat } & Titik Lokasi & \multicolumn{2}{c}{ Titik Koordinat } \\
1 & E: 104.499263 & N: 0.946402 & 16 & E: 104.501088 & N: 0.949093 \\
2 & E: 104.499569 & N: 0.946337 & 17 & E: 104.500582 & N: 0.949417 \\
3 & E: 104.499889 & N: 0.946674 & 18 & E: 104.501724 & N: 0.949437 \\
4 & E: 104.499507 & N: 0.946734 & 19 & E: 104.501257 & N: 0.949702 \\
5 & E: 104.499238 & N: 0.946974 & 20 & E: 104.500776 & N: 0.949914 \\
6 & E: 104.500206 & N: 0.947398 & 21 & E: 104.501826 & N: 0.949981 \\
7 & E: 104.499774 & N: 0.947438 & 22 & E: 104.501432 & N: 0.950398 \\
8 & E: 104.499467 & N: 0.947785 & 23 & E: 104.500999 & N: 0.950729 \\
9 & E: 104.500674 & N: 0.947932 & 24 & E: 104.501893 & N: 0.950868 \\
10 & E: 104.500206 & N: 0.948223 & 25 & E: 104.501525 & N: 0.951080 \\
11 & E: 104.499928 & N: 0.948548 & 26 & E: 104.501067 & N: 0.951125 \\
12 & E: 104.501092 & N: 0.948168 & 27 & E: 104.501847 & N: 0.951383 \\
13 & E: 104.500617 & N: 0.948538 & 28 & E: 104.501506 & N: 0.951482 \\
14 & E: 104.500178 & N: 0.948810 & 29 & E: 104.501186 & N: 0.951628 \\
15 & E: 104.501490 & N: 0.948783 & 30 & E: 104.501650 & N: 0.952182 \\
\hline
\end{tabular}

\subsection{Analisis Data}

Kelimpahan Fitoplakton

Kelimpahan fitoplankton dinyatakan secara kuantitatif dalam jumlah Sel/L. Kelimpahan plankton dihitung berdasarkan rumus sebagai berikut (Odum, 1993):

$$
\mathrm{N}=n x \frac{V r}{V 0} \times \frac{1}{V s}
$$

Keterangan :

$\mathrm{N} \quad=$ Kelimpahan fitoplankton (Sel/L)

$\mathrm{n} \quad=$ Jumlah individu yang diamati (Sel)

$\mathrm{Vr} \quad=$ Volume air yang tersaring $(\mathrm{mL})$

$\mathrm{VO}=$ Volume air yang diamati $(\mathrm{mL})$

Vs = Volume air yang disaring (L)

Indeks Similaritas Bray_Curtis

Indeks similaritas Bray-Curtis digunakan untuk melihat similatiras antarlokasi pengamatan melalui data kelimpahan fitoplankton. Indeks tersebut dapat diperoleh dengan menggunakan persamaan sebagai berikut (Krebs, 2014).

Keterangan :

$$
\mathrm{B}=\frac{\sum_{i=1}^{n}|\mathrm{Xij}-\mathrm{Xik}|}{\sum_{i=1}^{n} \mathrm{Xij}+\mathrm{Xik}}
$$

$\mathrm{B}$

$\mathrm{X}_{\mathrm{ij}}, \mathrm{Y}_{\mathrm{ik}} \quad$ = Nilai kelimpahan jenis-i pada tiap lokasi $(j, k)$

$\mathrm{n} \quad \quad=$ Jumlah jenis yang dibandingkan

Indeks Similaritas Canberra

Indeks similaritas Canberra dapat digunakan untuk melihat similaritas antarlokasi pengamatan melalui nilai fisikakimia perairan. Pengelompokan berdasarkan karateristik fisika-kimia perairan menggunakan indeks similaritas Canberra memiliki persamaan sebagai berikut (Krebs, 2014).

Keterangan :

$$
\mathrm{C}=\frac{1}{\mathrm{n}}\left[\sum_{i=1}^{n}\left(\frac{\sum_{i=1}^{n}|\mathrm{Xij}-\mathrm{Xik}|}{\sum_{i=1}^{n} \mathrm{Xij}+\mathrm{Xik}}\right)\right]
$$
C
$\mathrm{X}_{\mathrm{ij}}, \mathrm{Y}_{\mathrm{ik}}$
= Indeks similaritas Canberra
= Nilai fisika-kimia perairan pada tiap lokasi
= Jumlah parameter kualitas air yang dibandingkan 


\section{HASIL DAN PEMBAHASAN}

\subsection{Kondisi Kualitas Perairan Sei Timun}

Kondisi kualitas perairan menggambarkan kondisi parameter fisika dan kimia di Perairan Sei Tmun. Hasil pengukuran parameter kualitas perairan disajikan pada Tabel 2.

Tabel 2. Kondisi kualitas Perairan Sei Timun

\begin{tabular}{clccc} 
No & \multicolumn{1}{c}{ Parameter } & Satuan & \multicolumn{2}{c}{ Kualitas Air } \\
& Rata-rata & Baku Mutu* \\
1. & Kisika & & & \\
Kecerahan & Suhu & $\mathrm{cm}$ & $98,38 \pm 0,34$ & \\
3. & Salinitas & ${ }^{\circ} \mathrm{C}$ & $30,93 \pm 0,36$ & $28-32$ \\
4. & Kecepatan Arus & $\mathrm{ppt}$ & 0 & \\
5. & Kedalaman & $\mathrm{m} / \mathrm{s}$ & $0,1 \pm 0,04$ & \\
& Kimia & $\mathrm{cm}$ & $150,9 \pm 0,73$ & \\
1. & pH & & & \\
2. & DO & & $7,37 \pm 0,25$ & $6-9$ \\
3. & Nitrat & $\mathrm{mg} / \mathrm{L}$ & $6,60 \pm 0,31$ & $>4,0$ \\
4. & Fosfat & $\mathrm{mg} / \mathrm{L}$ & $0,08 \pm 0,5 \pm 0,08$ & 0,2 \\
\hline *P No.82 Tahun 2001 tentang Pengelolaan Kualitas Air dan Pengendalian Pencemaran Air
\end{tabular}

Rata-rata nilai kecerahan di Perairan Sei Timun sebesar 98,38 $\pm 0,34 \mathrm{~cm}$ dari kedalaman rata-rata perairan $150,97 \pm 0,73 \mathrm{~cm}$ dengan persentase $65,2 \%$. Nilai kecerahan dipengaruhi oleh keadaan cuaca, waktu pengukuran, kekeruhan dan padatan tersuspensi yang ada di dalam perairan (Rahman et al., 2016). Rata-rata salinitas di Perairan Sei Timun sebesar 0 ppt, dikarenakan perairan tersebut adalah perairan tawar. Fauzia et al. (2016) menyebutkan bahwa nilai salinitas untuk perairan tawar biasanya kurang 0,5 ppt dan perairan payau antara 0,5 - 30 ppt. Suhu di Perairan Sei Timun sebesar $30,93 \pm 0,36{ }^{\circ} \mathrm{C}$. Hal ini menunjukan bahwa suhu perairan tersebut sesuai untuk pertumbuhan fitoplankton. Hariyadi et al. (2010) mengatakan bahwa kisaran suhu optimum untuk laju pertumbuhan fitoplankton di perairan adalah $20-30^{\circ} \mathrm{C}$. Kelas Chlorophyceae tumbuh dengan baik pada kisaran $30-35^{\circ} \mathrm{C}$ dan kelas Bacillariophycea pada suhu $20-30^{\circ} \mathrm{C}$. Rata-rata kecepatan arus di Perairan Sei Timun sebesar 00, $1 \pm 0,04 \mathrm{~m} / \mathrm{s}$.

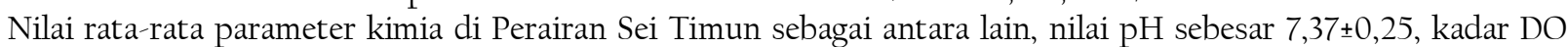

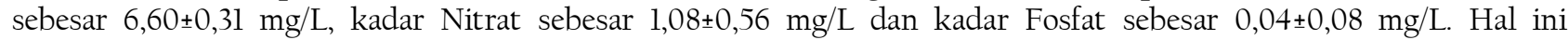
menunjukan bahwa nilai parameter kimia di Perairan Sei Timun memenuhi kriteria baku mutu PP No. 82 tahun 2001 tentang Pengelolaan Kualitas Air dan Pengendalian Pencemaran Air.

\subsection{Komposisi Jenis Fitoplankton Bacillariophyceae dan Chlorophyceae di Perairan Sei Timun}

Komposisi jumlah jenis fitoplankton kelas Bacillariophyceae dan Chlorophyceae yang ditemukan di Perairan Sei Timun terdiri dari 4 genera Bacillariophyceae dan 8 genera Chlorophyceae. Persentase jumlah fitoplankton di Perairan Sei Timun disajikan pada Gambar 2.

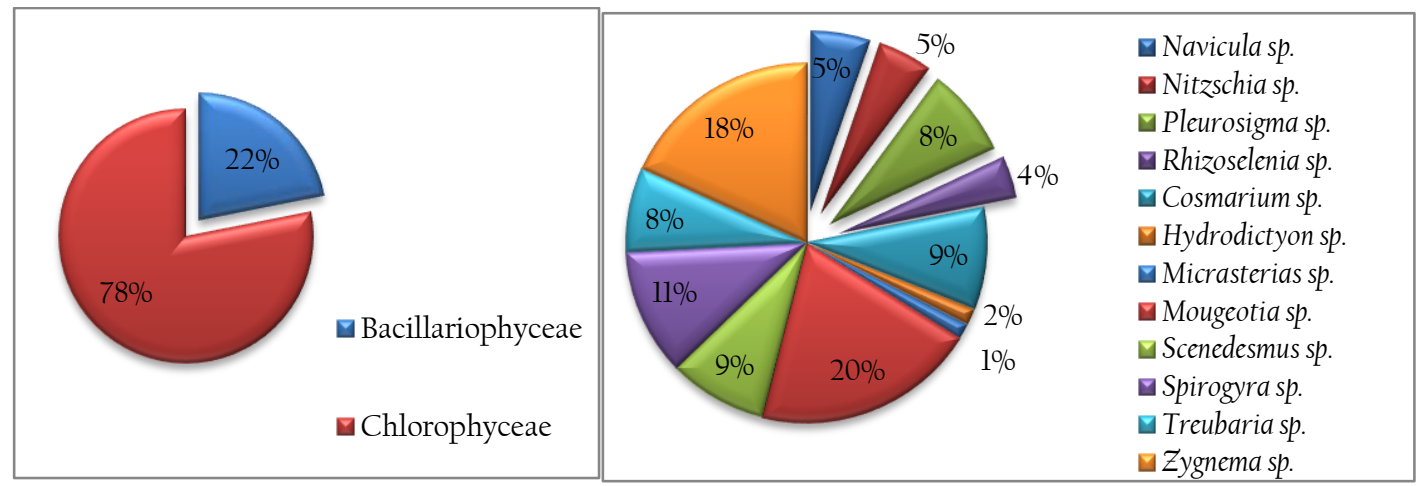

Gambar 2. Komposisi kelimpahan fitoplankton Bacillariophyceae dan Chlorophyceae (kiri) dan Komposisi jenis fitoplankton Bacillariophyceae dan Chlorophyceae (kanan) di Perairan Sei Timun

Berdasarkan Gambar 2. diketahui bahwa komposisi jumlah jenis fitoplankton kelas Chlorophyceae lebih tinggi daripada kelas Bacillariophyceae dengan persentase sebesar 78\% dan 22\%. Kelas Chlorophyceae yang komposisi jenis paling tinggi yaitu genera Mougeotia sp. Sebesar 20\% dan yang terendah genera Micrasterias sp. sebesar 1\%. Tingginya persentase komposisi jenis kelas Chlorophyceae dibandingkan dan kelas Bacillariophyceae yang ditemukan di Perairan Sei Timun ini sesuai dengan pernyataan dari Ambarwati et al. (2014), Chlorophyceae umumnya banyak ditemukan di perairan air tawar karena sifatnya mudah beradaptasi dan cepat berkembangbiak, sehingga populasinya banyak 
ditemukan di perairan tawar. Fitoplankton dari kelas Chlorophyceae umumnya melimpah di perairan dengan intensitas cahaya yang cukup seperti kolam, danau dan waduk.

Kelas Bacillariophyceae yang ditemukan di Perairan Sei Timun, dengan komposisi jenis yang paling tinggi yaitu genera Pleurogsima sp. sebesar 8\% dan terendah genera Rhizoselenia sp. sebesar 4\%. Menurut Usman et al. (2013), kelas Bacillariophyceae mampu tumbuh dengan cepat meskipun pada kondisi cahaya yang rendah, hal tersebut juga dikarenakan jenis fitoplankton ini mempunyai kemampuan beradaptasi dengan baik sehingga mampu meregenerasi dan bereproduksi dalam jumlah yang lebih besar dari jenis fitoplankton yang lain.

\subsection{Kelimpahan Fitoplankton Kelas Bacillariophyceae dan Chlorophyceae di Perairan Sei Timun}

Jenis dan kelimpahan rata-rata fitoplankton kelas Bacillariophyceae dan Chlorophyceae yang ditemukan di Perairan Sei Timun dapat dilihat pada Tabel 3.

Tabel 3. Jenis dan kelimpahan rata-rata fitoplankton kelas Bacillariophyceae dan Chlorophyceae

\begin{tabular}{clc} 
Kelas & \multicolumn{1}{c}{ Jenis } & Kelimpahan rata-rata (sel/L) \\
Bacillariophyceae & Navicula sp. & 1116,6 \\
& Nitzschia sp. & 1044,7 \\
& Pleurosigma sp. & 1701,4 \\
& Rhizoselenia sp. & 799,1 \\
Chlorophyceae & Cosmarium sp. & 1935,6 \\
& Hydrodictyon sp. & 314,9 \\
& Micrasterias sp. & 302,2 \\
& Mougeotia sp. & 4276,6 \\
& Scenedesmus sp. & 1881,7 \\
Spirogyra sp. & 2426,9 \\
& Treubaria sp. & 1616,4 \\
Zygnema sp. & 3883,3 \\
& Total & 21299,4 \\
\hline
\end{tabular}

Berdasarkan Tabel 3. diketahui bahwa kelimpahan total rata-rata fitoplantkon kelas Bacillariophyceae dan Chlorophyceae di Perairan Sei Timun sebesar 21299,4 sel/L. Kelimpahan rata-rata tertinggi pada kelas Bacillariophyceae yaitu genera Pleurosigma sp. sebesar 1701,4 sel/L dan kelimpahan rata-rata terendah yaitu pada genera Rhizoselenia sp. sebesar 799,1 sel/L, sedangkan kelimpahan rata-rata tertinggi pada kelas Chlorophyceae yaitu pada genera Mougeotia sp. sebesar 4276,6 sel/L dan kelimpahan rata-rata terendah yaitu pada genera Micrasterias sp. sebesar 302,2 sel/L.

\subsection{Pengelompokan Lokasi Berdasarkan Kelimpahan Bacillariophyceae dan Chlorophyceae di Perairan Sei Timun}

Dendogram pengelompokan lokasi berdasarkan kelimpahan fitoplankton kelas Bacillariophyceae dan Chlorophyceae di Perairan Sei Timun disajikan dalam Gambar 3.

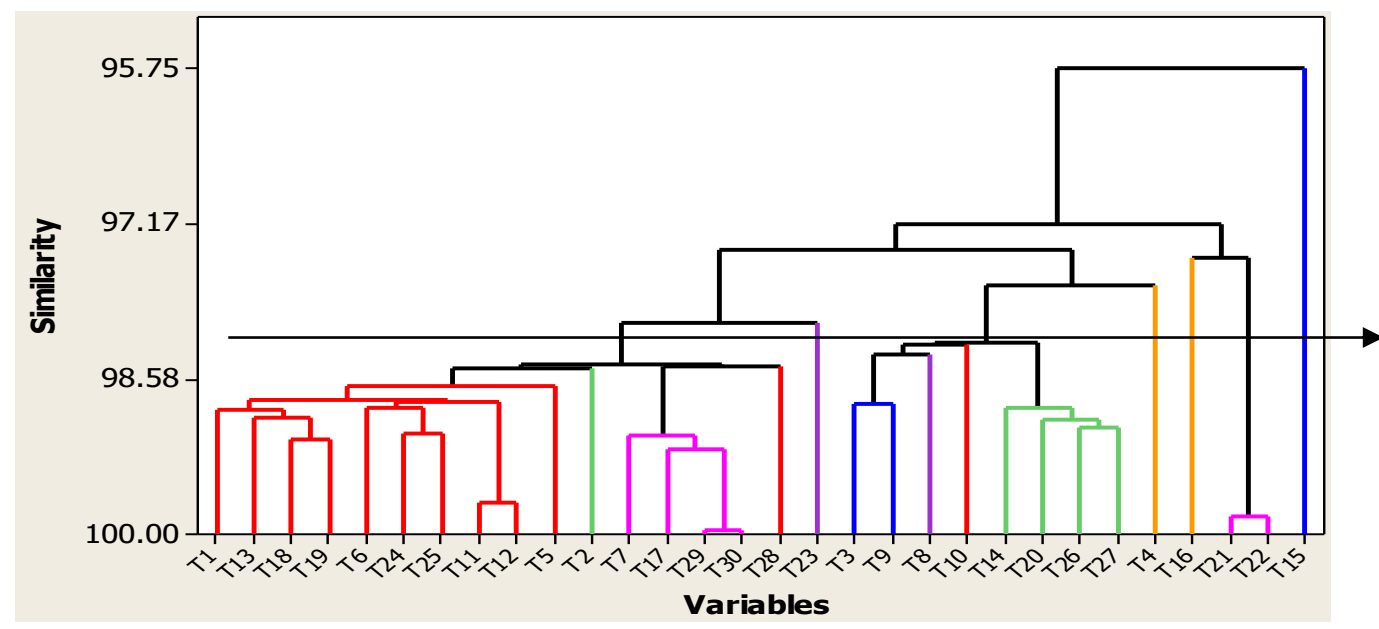

Gambar 3. Dendogram pengelompokan lokasi berdasarkan kelimpahan Bacillariophyceae dan Chlorophyceae di Perairan Sei Timun

Berdasarkan Gambar 3. terlihat bahwa pada perpotongan taraf similaritas 98,56\%, terbentuk menjadi 13 kelompok yaitu : 1) kelompok 1 terdiri dari titik T1, T5, T6, T11, T12, T13, T18, T19,dan T24 dengan tingkat kesamaan 98,58\%. 2). Kelompok 2 diwakili titik T2. 3). Kelompok 3 terdiri dari titik T7, T17, T29 dan T30 dengan tingkat kesamaan sebesar 98,40\%. 4). Kelompok 4 diwakili titik T28. 5). Kelompok 5 diwakili titik T23. 6). Kelompok 6 terdiri dari titik T3dan T9 dengan tingkat kesamaan sebesar 98,20\%. 7). Kelompok 7 diwakili titik T8. 8). Kelompok 8 diwakili titik T10. 9). 
Kelompok 9 terdiri dari titik T14, T20, T26 dan T27 dengan tingkat kesamaan sebesar 98,10\%. 10). Kelompok 10 diwakili titik T4. 11). Kelompok 11 diwakili titik T16. 12). Kelompok 12 terdiri dari titik T21 dan T22 dengan tingkat kesamaan 97,80\%. 13). Kelompok 13 diwakili oleh titik T15.

\subsection{Pengelompokan Lokasi Bedasarkan Nilai Fisika-Kimia di Perairan Sei Timun}

Pengelompokan lokasi berdasarkan parameter fisika-kimia perairan digunakan Indeks similaritas Canberra. Analisis similaritas dilakukan menggunakan minitab dengan analisis cluster multivariat. Dendogram pengelompokan lokasi berdasarkan karakteristik parameter fisika dan kimia perairan Sei Timun disajikan dalam Gambar 4.

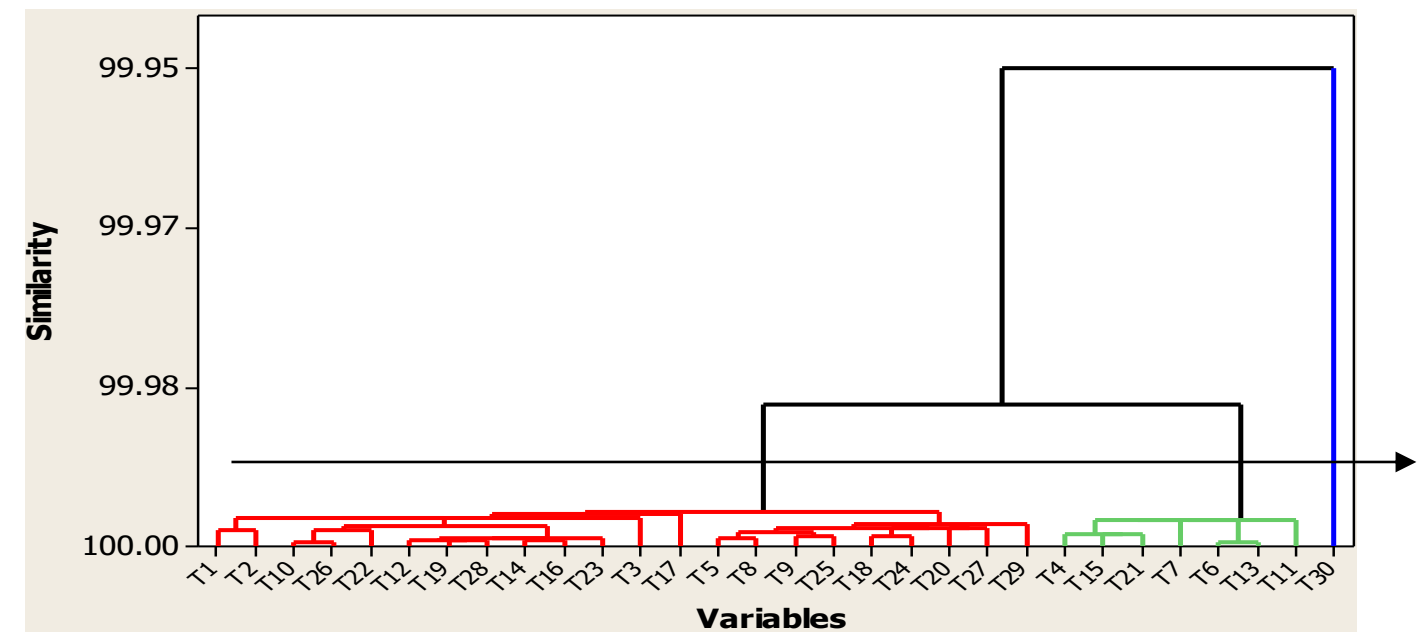

Gambar 4. Dendogram pengelompokan lokasi berdasarkan parameter fisika dan kimia di Perairan Sei Timun

Berdasarkan gambar 8. terlihat bahwa pada perpotongan taraf similaritas 99,99\%, terbentuk menjadi 3 kelompok yaitu, 1). Kelompok 1 terdiri dari titik T1, T2, T3, T5, T8, T9, T10, T12, T14, T16, T17, T18, T19, T20, T22, T23, T24, T25, T26, T27, T28, dan T29. 2). Kelompok 2 terdiri dari titik, T4, T6, T7, T11, T13, T15, dan T2l. Kelompok 3 diwakili T30.

Kelompok 1 merupakan kelompok terbesar dengan tingkat kesamaan yang tinggi yaitu 99,99\% diduga karena semua parameter terukur memiliki nilai yang hampir sama terutama parameter $\mathrm{pH}$, suhu, DO, kecepatan arus, kandungan nitrat dan fosfat. Kelompok 2, membentuk kelompok sendiri hal ini diduga karena memiliki nilai kecerahan paling terendah diantara stasiun-stasiun lainnya.

\section{SIMPULAN}

Eksistensi atau keberadaan fitoplankton kelas Bacillariophyceae sebanyak 4 genera yaitu Navicula sp., Nitzschia sp., Pleurosigma sp., dan Rhizoselenia sp. dengan kelimpahan total rata-rata sebesar 4661,8 sel/L. Pleurosigma sp. merupakan genera dominan yang dijumpai dengan kelimpahan rata-rata sebesar 1701,4 sel/L. Kelas Chlorophyceae sebanyak 8 genera yaitu Cosmarium sp., Hydrodiction sp., Micrasterias sp., Mougeotia sp., Scenedesmus sp., Spirogyra sp., Treubaria sp. dan Zygnema sp. dengan kelimpahan total rata-rata sebesar 16637,6 sel/L. Mougeotia sp. merupakan genus dominan yang dijumpai dengan kelimpahan rata-rata sebesar 4276,6 sel/L.

\section{UCAPAN TERIMA KASIH}

Penulis menyampaikan ucapan terima kasih kepada Kepala Laboratorium Riset dan Kepala Laboratorium Edukasi Fakultas Ilmu Kelautan dan Perikanan UMRAH, serta staf laboratorium yang telah membantu selama proses penelitian.

\section{REFERENSI}

Ambarwati, Saifullah, \& Mustahal. (2014). Identifikasi Fitoplankton dari Perairan Waduk Nadra Krenceng Kota Cilegon Banten. Jurnal Perikanan dan Kelautan. 4(4): 283-291.

Azizah, D. (2017). Kajian Kualitas Lingkungan Perairan Teluk Tanjungpinang Provinsi Kepulauan Riau. Dinamika Maritim, 6(1): $47-53$. Basmi, J. (1999). Planktonologi: Bioekologi Plankton Algae. Fakultas Perikanan dan Ilmu Kelautan. IPB Bogor. 110p.

Fauzia, A.Z., Suhartini, \& Sudarsono. (2016). Kualitas Perairan di Sungai Bedog, Yogyakarta Berdasarkan Keanekaragaman Plankton. Jurnal Biologi, 5(6): 50-61.

Hariyadi, S., Adiwilaga, E.M., Pratono, T., Hardjoamidjojo, S., \& Damar, A. (2010). Produktivitas Primer Estuari Sungai Cisadane Pada Musim Kemarau. Limnotek, 17(1): 49-57.

Kerbs, C. J. (2004). Ecological Methodology. Menlo Park, California: Benjamin/ Cummings. 
Lestari, F. (2018). Pollution Charges and Assimilation Capacity in Tanjungpinang Bay Area, Riau Islands Province, Indonesia. Asian Journal of Water, Environment and Pollution, 15(1): 1-7.

Nybakken. (1992). Biologi Laut. PT GRAMEDIA. Jakarta. 459p.

Odum, E.P. (1993). Dasar-Dasar Ekologi Edisi Ketiga. Terjemahan : Samingan, T., Srigandono. Fundamentals Of Ecology. Third Edition. Gadjah Mada Univerity Press. Yogyakarta.

Peraturan Pemerintah Republik Indonesia No.82 Tahun 2001 tentang Pengelolaan Kualitas Air dan Pengendalian Pencemaran Air.

Rahman, E.C., Masyamsir, dan Rizal, A. (2016). Kajian Variabel Kualitas Air dan Hubungannya dengan Produktivitas Primer Fitoplankton di Perairan Waduk Darma Jawa Barat. Jurnal Perikanan Kelautan, 7(1): 93-102.

Syafriani, R., \& Apriadi, T. (2017). Keanekaragaman Fitoplankton di Perairan Estuari Sei Terusan, Kota Tanjungpinang. Limnotek, 24(2): 74-82.

Usman, M.S., Kusen, J.D., \& Rimper, J.R.T.S.L. (2013). Struktur Komunitas Plankton di Perairan Pulau Bangka Kabupaten Minahasa Utara. Jurnal Pesisir dan Laut Tropis, 1(2): 51-57.

Yuliana, Adiwilaga, E.M., Harris, \& E., Pratiwi. (2012). Hubungan Antara Kelimpahan Fitoplankton dengan Parameter Fisik-Kimiawi Perairan di Teluk Jakarta. Jurnal Akuatika, 3(2): 169-179. 